\title{
Negative feedforward control of body fluid homeostasis by hepatorenal reflex
}

\author{
Hironobu Morita and Chikara Abe
}

The liver, well known for its role in metabolism, clearance and storage can also be regarded as a sensory organ. The liver is an ideal place to monitor the quality and quantity of absorbed substances, because portal blood delivers substances absorbed from the intestine to the liver and these substances circulate in the hepatic vasculature before substances enter the systemic circulation. Sodium $\left(\mathrm{Na}^{+}\right)$-sensitive mechanism exists in the liver; it is stimulated by the increase in $\mathrm{Na}^{+}$concentration in the portal vein, and then hepatorenal reflex is triggered. Renal sympathetic nerve activity is reflexively decreased and urinary $\mathrm{Na}^{+}$ excretion is increased. This $\mathrm{Na}^{+}$-sensitive hepatorenal reflex has a significant role in post-prandial natriuresis. However, the long-term role of this reflex in $\mathrm{Na}^{+}$homeostasis may be less important, probably because of the desensitization of $\mathrm{Na}^{+}$-sensitive mechanisms. $\mathrm{Na}^{+}-\mathrm{K}^{+}-2 \mathrm{Cl}^{-}$cotransporter (NKCC1) is involved in the hepatoportal $\mathrm{Na}^{+}$-sensitive mechanism, and $\mathrm{NKCC1}$ expression is reduced if the hepatoportal region is exposed to high $\mathrm{Na}^{+}$concentrations for a long time. This situation occurs when animals intake a high-sodium chloride diet for a long time. Liver cirrhosis also impairs the $\mathrm{Na}^{+}$-sensitive hepatorenal reflex. Hepatoportal baroreceptor-induced renal sympathetic excitation and the impaired $\mathrm{Na}^{+}$-sensitive hepatorenal reflex may partially explain the $\mathrm{Na}^{+}$retention in liver cirrhosis.

Hypertension Research (2011) 34, 895-905; doi:10.1038/hr.2011.88; published online 30 June 2011

Keywords: hepatorenal reflex; hepatic afferent nerve; liver cirrhosis; post-prandial natriuresis; renal sympathetic nerve

It is well documented that the mammalian liver is not only a metabolic, clearance and storage organ but also contains many receptors, including osmoreceptors, ${ }^{1,2}$ baroreceptors ${ }^{3,4}$ and ionic receptors. ${ }^{5-7}$ Given the roles that these receptors have in the systemic circulation, it is possible that they are also involved in the regulation of body fluid homeostasis. A growing body of evidence suggests that the osmoreceptors and ionic receptors in the liver and its vasculature detect a variety of physiological events and are responsible for the activation of a number of physiological responses, which may have important roles in the regulation of body fluid homeostasis. The important features of the hepatic sensor mechanism are: (1) substances consumed orally are absorbed from the intestine into the blood, circulate in the hepatic vasculature and then enter the systemic circulation; and (2) the portal venous blood flow is $20-25 \%$ of the cardiac output. Because of these features, the hepatic osmoreceptors and ionic receptors have advantages over those receptors located in the systemic circulation. First, the hepatic receptors are triggered by changes in portal venous osmolality and ionic concentration before any changes occur in the systemic blood, and then reflexively regulate renal excretion and intestinal absorption. ${ }^{7-10}$ Second, the concentrations of the absorbed substances in the hepatoportal region and the changes in them are 4-5 times greater than those in the systemic circulation. Therefore, the hepatoportal receptors could easily detect these changes. Accordingly, the liver is the ideal place to monitor the quality and quantity of these substances and transduce them into hepatic afferent nerve activity. If the purpose of the hepatic osmo- and ionic receptors is to regulate the homeostasis of systemic body fluids, but not the portal venous osmolality or ionic concentration, they would predict the systemic blood osmolality and ionic concentration from the portal venous components. This prediction could result in errors of regulation. This error in control could be corrected by other negative feedback systems located in the systemic circulation. In this paper, we review the literature concerning the role of the liver in body fluid homeostasis.

\section{OSMORECEPTORS OR SODIUM (NA ${ }^{+}$) RECEPTORS IN THE LIVER}

Haberich and coworkers ${ }^{11,12}$ first suggested the existence of osmoreceptors in the hepatoportal region. Using chronically implanted conscious rats, they showed that the infusion of water into the hepatic portal vein produced a rapid increase in urine flow, whereas a similar infusion into the vena cava had less effect. Further evidence has been provided by electrophysiological studies, most of which were conducted in situ, with the liver perfused while the hepatic afferent nerve activity was measured. ${ }^{1,2,5,13,14}$ Niijima $^{2}$ recorded afferent discharges from the hepatic branch of the vagal nerve of the perfused guinea pig liver, and demonstrated that increasing the perfusate osmolality with sodium chloride $(\mathrm{NaCl})$ caused a dose-dependent increase in the 
discharge rate. Similar effects were produced using hypertonic Ringer solutions, prepared by the addition of mannose, glucose or sucrose. He concluded that the afferent discharge of the hepatic vagal nerve is directly related to the osmolality of the perfusate, rather than to the $\mathrm{NaCl}$ concentration. These results are at variance with those reported by Andrews and Orbach, ${ }^{5}$ who suggested that only the $\mathrm{Na}^{+}$receptor, which is not a true osmoreceptor, is involved in the hepatic vagal afferents of the rabbit. In that study, the hepatic afferent nerve activity increased with the addition of a hypertonic solution with extra $\mathrm{NaCl}$, but not with one supplemented with mannitol or sucrose.

Adachi et al. ${ }^{1}$ examined 78 hepatic vagal nerve bundles in perfused rat liver and found three types of responses: the discharge rate increased in 21 bundles in response to hyperosmolality; the discharge rate increased in 14 bundles in response to hypoosmolality; and there was no response to osmotic stimulation in 35 bundles. $\mathrm{NaCl}$ was the most effective stimulant, although the hyperosmolality produced with urea or sucrose also activated the receptor, but the magnitude of the response was considerably less than that elicited with equiosmotic amounts of $\mathrm{NaCl}$. In this context, the differences in osmolality and tonicity (effective osmolality) should be noted. Tonicity is defined as a property of a solution with reference to a particular membrane, whereas osmolality is a property of a particular solution and is independent of any membrane. However, the activity of the hepatic afferent branch of the anterior hepatic plexus increases in response to the portal venous infusion of hypertonic $\mathrm{NaCl}$ or sodium bicarbonate $\left(\mathrm{NaHCO}_{3}\right)$, but not of lithium chloride ( $\mathrm{LiCl}$ ) or mannitol (Figure 1), indicating that an $\mathrm{Na}^{+}$-sensitive mechanism but not an tonicitysensitive mechanism exists in the hepatoportal region.

\section{NEUROANATOMY OF THE LIVER}

The mammalian liver is innervated by both sympathetic and parasympathetic nerves, although there are many individual and species differences in their sources and distributions, and both types of nerves contain afferent and efferent fibers. These nerves enter the liver with the hepatic vasculature and bile ducts. The nerves of the liver, gall bladder and bile ducts form a plexiform structure, which is subdivided into an anterior and a posterior hepatic plexus. ${ }^{15,16}$ The anterior plexus is located around the hepatic artery, and derives mainly from the left portion of the celiac plexus and the right abdominal branch of the left vagus, which approaches through the hepatogastric ligament. The posterior plexus is located around the portal vein and the bile duct, and derives from the right portion of the celiac plexus and the branches of the right vagus.

The vagal afferent innervation is predominantly through the left nodose ganglion and common hepatic branch, with a minor contribution through the right nodose ganglion and vagus/celiac branch. However, the major portion of the common hepatic branch does not serve the liver, portal vein or bile ducts, but innervates the duodenum, pancreas, pylorus and distal gastric antrum. ${ }^{17}$ Spinal sensory innervation is achieved through dorsal root afferents at the thoracic spinal level of T7-T13. The question of intrahepatic afferent innervation is of central importance to the present discussion because it transmits information from the hepatic sensory receptors. However, unlike other important organs, the vagal and spinal afferent innervation of the portal and hepatic areas has not been thoroughly studied. It is generally agreed that sensory nerve fibers of either a vagal or a dorsal root/spinal origin do not directly innervate hepatocytes, but are restricted to the stroma surrounding the triads of the hepatic vasculature and the bile ducts, and to the extrahepatic portions of the portal vein and bile ducts. ${ }^{18}$

\section{Portal venous injection of hypertonic solution $(0.5 \mathrm{ml} / \mathrm{kg} \mathrm{b.w}$.)}
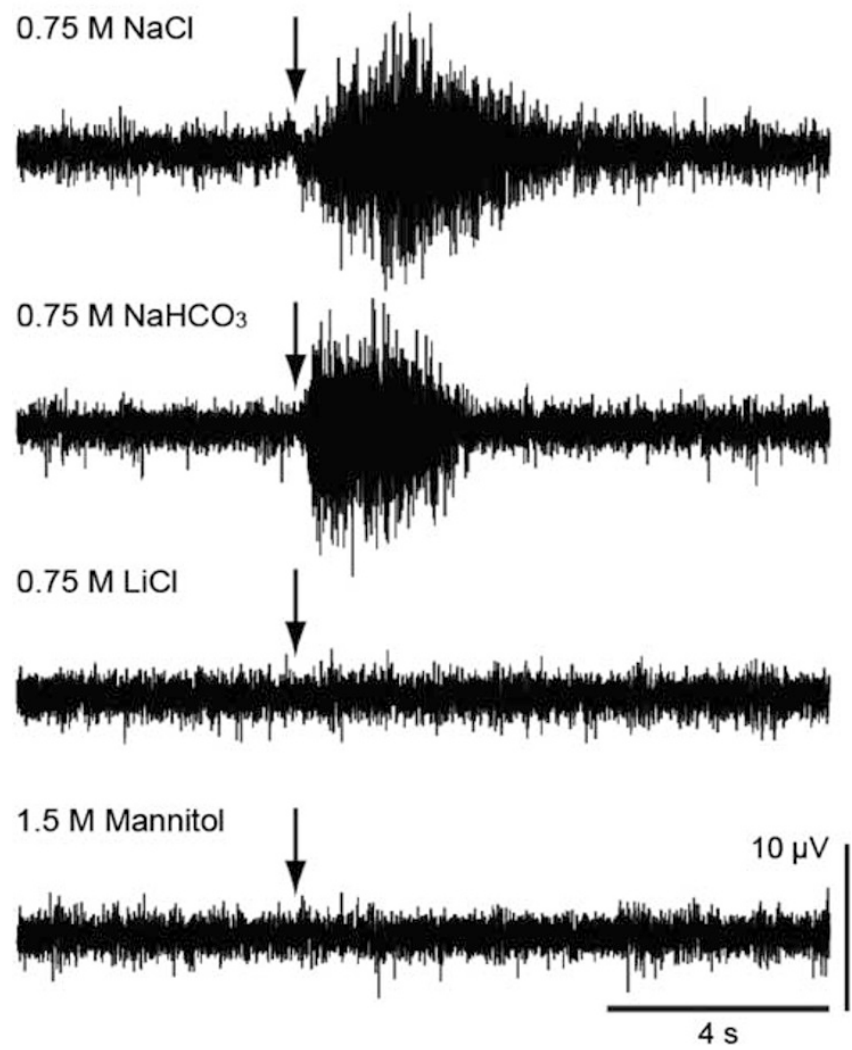

Figure 1 Original records illustrating the periarterial hepatic afferent nerve activity in response to an intraportal injection $\left(0.5 \mathrm{ml} \mathrm{kg}^{-1}\right.$ body weight) of hypertonic $\mathrm{NaCl}, \mathrm{NaHCO}_{3}$, $\mathrm{LiCl}$ or mannitol.

\section{$\mathrm{NA}^{+}$RECEPTOR}

The periarterial hepatic nerve responds to hypertonic $\mathrm{NaCl}$, but not to hypertonic $\mathrm{LiCl}$ or mannitol, suggesting that it may sense the $\mathrm{Na}^{+}$ concentration, rather than tonicity. ${ }^{19} \mathrm{Na}^{+}$-sensitive mechanisms also exist in areas outside the hepatoportal region, that is, in the taste buds and macula densa, which sense $\mathrm{Na}^{+}$via the amiloride-sensitive $\mathrm{Na}^{+}$channel and furosemide-sensitive $\mathrm{Na}^{+}-\mathrm{K}^{+}-2 \mathrm{Cl}^{-}$cotransporter (NKCC), respectively. ${ }^{20-23}$ Therefore, it is possible that the hepatoportal $\mathrm{Na}^{+}$-sensitive mechanism senses the $\mathrm{Na}^{+}$concentration via these $\mathrm{Na}^{+}$transport systems. To examine this, the responses of the periarterial hepatic afferent nerve activity to an intraportal injection of hypertonic $\mathrm{NaCl}$ solution were examined with or without inhibitors of the $\mathrm{Na}^{+}$transport systems. ${ }^{6}$ The $\mathrm{Na}^{+}-\mathrm{H}^{+}$exchanger and $\mathrm{Na}^{+}-\mathrm{HCO}_{3}{ }^{-}$ cotransporter are inhibited by amiloride and SITS (4-acetamido- $4^{\prime}-$ isothiocyanato-stilbene-2,2'-disulfonic acid), respectively, and are involved in hepatocellular $\mathrm{pH}$ regulation. ${ }^{24,25} \mathrm{NKCC} 1$ is inhibited by bumetanide, and is involved in hepatocellular volume regulation. ${ }^{25,26}$ Bumetanide, but not amiloride or SITS, dose-dependently suppressed the hepatic afferent nerve responses to intraportal hypertonic $\mathrm{NaCl}$ injection, suggesting that the NKCC1 is involved in hepatoportal $\mathrm{Na}^{+}$ sensing (Figure 2).

Although the link between the NKCC1 and the increase in hepatic afferent nerve activity is unclear, two possibilities can be considered. First, the hepatic nerve terminal might be in contact with a hepatocyte that bears NKCC1. Because NKCC1 is known to regulate hepatocellular 
Dose response to $0.75 \mathrm{M} \mathrm{NaCl}$
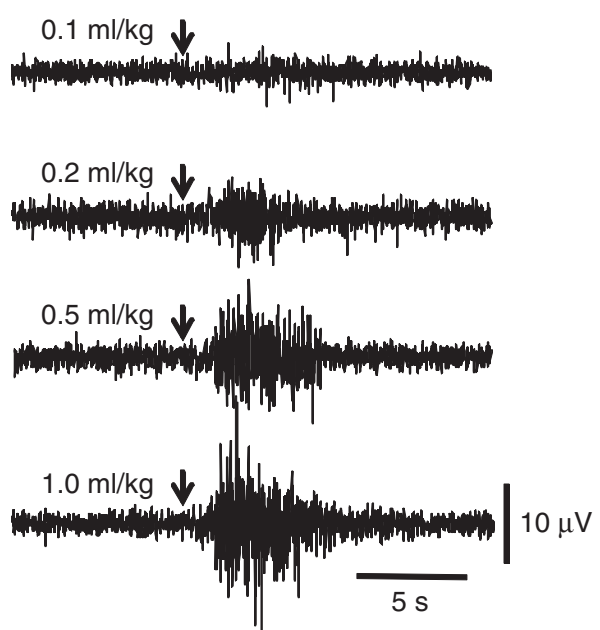

Amiloride

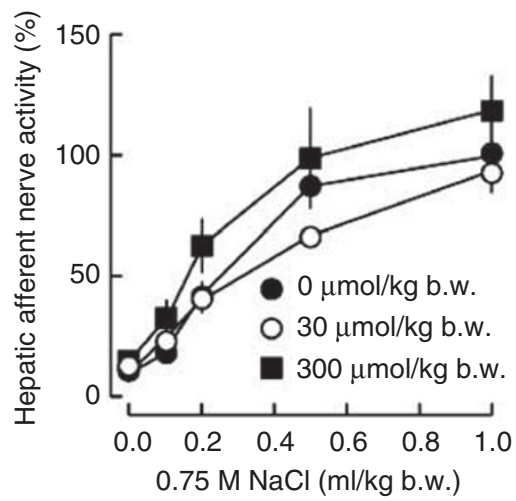

Amiloride

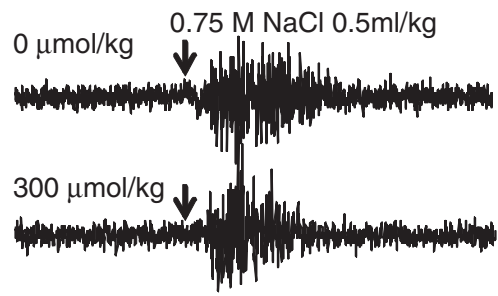

Bumetanide

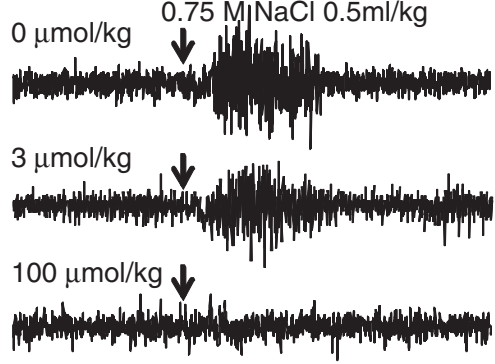

Bumetanide

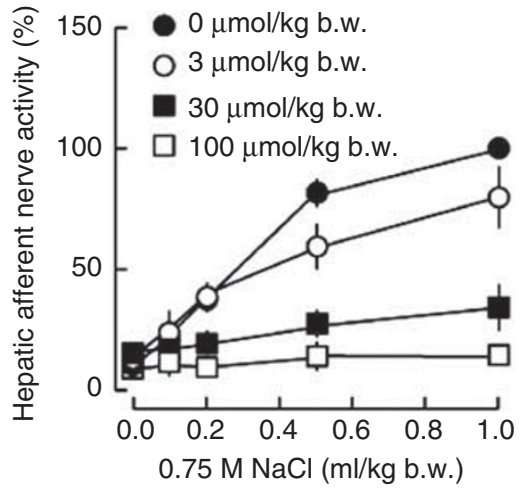

Figure 2 Upper panel: original records illustrating the hepatic afferent nerve activity in response to an intraportal bolus injection of $0.75 \mathrm{M} \mathrm{NaCl}$ (shown by the arrowheads). The left panel shows the dose-dependence of the hepatic afferent nerve activity at $0.75 \mathrm{~m} \mathrm{NaCl}$. The right panel shows the effects of amiloride $\left(300 \mu \mathrm{mol} \mathrm{kg}{ }^{-1}\right.$ body weight into the portal vein) or bumetanide ( 3 and $100 \mu \mathrm{mol} \mathrm{kg}^{-1}$ body weight into the portal vein) pretreatment on the hepatic afferent nerve response to an intraportal injection of $0.75 \mathrm{~m} \mathrm{NaCl}$. Lower panel: summary data showing the responses of hepatic afferent nerve activity to an intraportal bolus injection of $0.75 \mathrm{~m} \mathrm{NaCl}$ before and after the intraportal infusion of amiloride (left) or bumetanide (right). Modified from (Morita et al. ${ }^{6}$ )

volume, ${ }^{25,26}$ if the basolateral $\mathrm{NaCl}$ concentration is increased, the cellular volume will also increase, and this might stretch and stimulate the nerve terminal. Second, the nerve terminal itself might bear $\mathrm{NKCC1}$, and an increase in the $\mathrm{NaCl}$ concentration of the portal blood might depolarize the nerve terminal. In this context, it is interesting to note that increases in the luminal $\mathrm{NaCl}$ concentration depolarize macula densa cells, and the alterations in the basolateral membrane potential of macula densa cells induced by changes in the luminal $\mathrm{NaCl}$ concentration are blocked by furosemide. ${ }^{20,22,23}$

\section{CENTRAL PATHWAY}

Kobashi and Adachi ${ }^{27-29}$ extensively examined the central projection of the hepatoportal $\mathrm{Na}^{+}$-sensitive and/or osmosensitive mechanisms. They demonstrated that certain neurons in the nucleus of the solitary tract respond to the intraportal infusion of hypertonic $\mathrm{NaCl}$ solution, and these units project to the caudal ventrolateral medulla, parabrachial nucleus and dorsal hypothalamus. Schmitt ${ }^{30}$ recorded single unit activity in the hypothalamus, zona incerta (a central region that may be involved in the regulation of osmoregulatory behaviors) and ventral thalamus, and identified neurons that respond to the intraportal infusion of hypertonic $\mathrm{NaCl}$ solution but not to isotonic solution or a jugular infusion of hypertonic $\mathrm{NaCl}$ solution.

To further examine the central projection of the hepatoportal $\mathrm{Na}^{+}-$ sensitive mechanism, Fos expression was examined in response to a portal infusion of hypertonic solution. ${ }^{19}$ In this study, the hepatoportal $\mathrm{Na}^{+}$-sensitive mechanism was stimulated by the simultaneous infusion of $0.45-\mathrm{M} \mathrm{NaCl}$ into the portal vein and distilled water into the inferior vena cava in conscious rats, to keep the total amount of solution introduced into the systemic circulation isotonic, thus avoiding changes in the plasma osmolality and $\mathrm{NaCl}$ concentration. Intense Fos expression was observed in the osmoregulatory center, that is, the area postrema, nucleus of the solitary tract, paraventricular hypothalamic nucleus and supraoptic nucleus. However, few, if any Fos-positive cells were found when the rats were hepatically denervated or if they received an intraportal infusion of hypertonic $\mathrm{LiCl}$ or mannitol (Figure 3). Therefore, it is possible that the osmoregulatory 


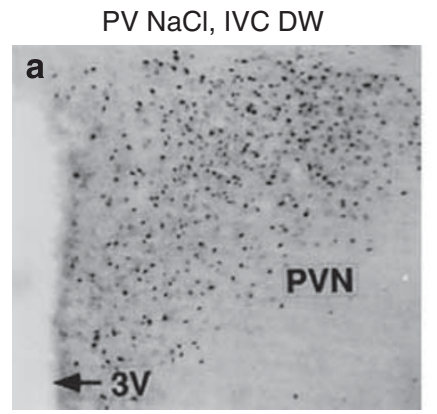

$\mathrm{HD}, \mathrm{PV} \mathrm{NaCl}, \mathrm{IVC}$ DW
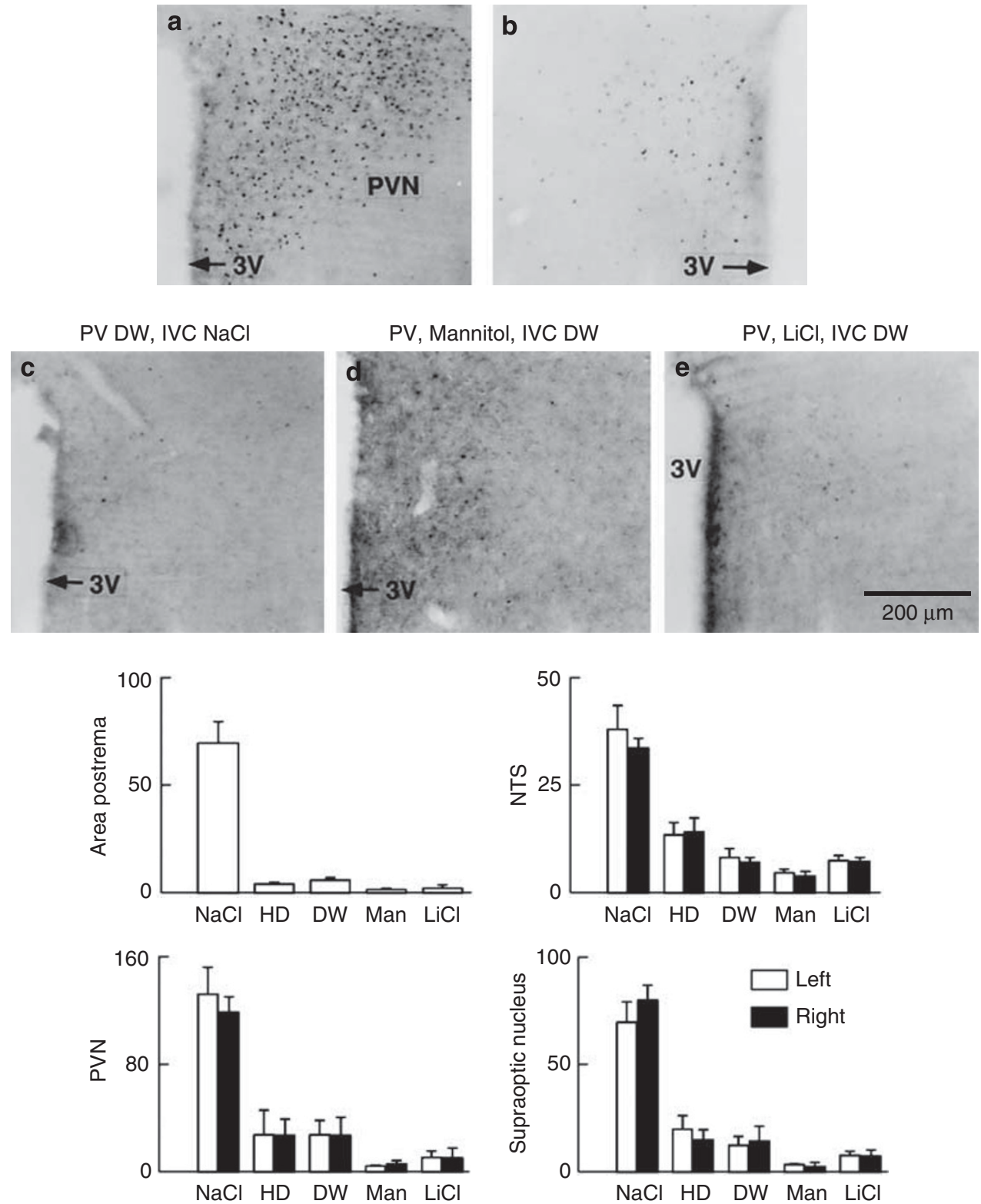

Figure 3 Upper panel: (a) coronal sections through the paraventricular hypothalamic nucleus of a rat simultaneously infused with hypertonic $\mathrm{NaCl}$ into the portal vein (PV) and distilled water (DW) into the inferior vena cava (IVC); (b) a hepatic-denervated rat (HD) simultaneously infused with hypertonic NaCl into the PV and DW into the IVC; (c) a rat simultaneously infused with DW into the PV and hypertonic $\mathrm{NaCl}$ into the IVC; (d) a rat simultaneously infused with hypertonic mannitol into the PV and DW into the IVC; and (e) a rat simultaneously infused with hypertonic LiCl into the PV and DW into the IVC. Lower panel: comparisons of means \pm s.e.m. of Fos-positive cells from the area postrema, nucleus of the solitary tract (NTS), paraventricular hypothalamic nucleus (PVN) and supraoptic nucleus. $\mathrm{NaCl}$ : rats simultaneously infused with hypertonic $\mathrm{NaCl}$ into the PV and DW into the IVC; HD: hepatic-denervated rats simultaneously infused with hypertonic $\mathrm{NaCl}$ into the PV and DW into the IVC; DW: rats simultaneously infused DW into the PV and hypertonic NaCl into the IVC; Man: rats simultaneously infused with hypertonic mannitol into the PV and DW into the IVC; LiCl: rats simultaneously infused with hypertonic LiCl into the PV and DW into the IVC. Modified from (Morita et al. ${ }^{19}$ ).

center is activated by stimulation of the hepatoportal $\mathrm{Na}^{+}$-sensitive mechanism, but is not activated by stimulation of the hepatoportal osmosensitive mechanism.

The intense expression of Fos in the paraventricular hypothalamic nucleus and supraoptic nucleus suggests that the stimulation of the hepatoportal $\mathrm{Na}^{+}$-sensitive mechanism enhances vasopressin release. However, the control of vasopressin release by the hepatoportal
$\mathrm{Na}^{+}$-sensitive and/or osmosensitive mechanisms is still controversial. Intragastric hypertonic $\mathrm{NaCl}$ infusion, which increased portal venous osmolality but had no effect on plasma osmolality, increased vasopressin release, with significant Fos expression, in the area postrema, nucleus of the solitary tracts, supraoptic nucleus and paraventricular hypothalamic nucleus. ${ }^{31}$ However, the vasopressin response was affected by neither subdiaphragmatic vagotomy nor splanchnic 
denervation, whereas Fos expression was reduced in the nucleus of the solitary tract and area postrema by splanchnic denervation, and in the paraventricular hypothalamic nucleus and supraoptic nucleus by subdiaphragmatic vagotomy. The combined effect of vagotomy and splanchnic denervation was not examined. ${ }^{32}$ In contrast, Choi-Kwon and Baertschi ${ }^{33}$ reported that bilateral splanchnic denervation attenuated the vasopressin response induced by intragastric $\mathrm{NaCl}$ infusion by $\sim 60 \%$, whereas bilateral vagotomy had no effect. They concluded that the response was mediated by splanchnic afferents. Electrophysiological evidence reported by Baertschi and colleagues ${ }^{34,35}$ supports this idea. They demonstrated that an intraportal hypertonic $\mathrm{NaCl}$ infusion increased the firing rates of the hypothalamoneurohypophysial tract and supraoptic nucleus endocrine neurons. Bilateral cervical vagotomy had no effect on this response, but injection of local anesthetic into the spinal cord at thoracic levels abolished the response.

\section{HEPATORENAL REFLEX FOR NA ${ }^{+}$REGULATION}

It is well known that the noradrenaline-containing renal sympathetic nerve terminates in the peritubular basement membrane of all renal tubular segments, as well as in the juxtaglomerular granular cells. ${ }^{36}$ Alterations in renal sympathetic nerve activity could alter renal $\mathrm{Na}^{+}$ excretion through changes in renal tubular transport and renin release. ${ }^{37}$ Acute volume expansion induced with an isotonic solution reduced renal sympathetic nerve activity and then increased renal $\mathrm{Na}^{+}$ excretion, which was attenuated by renal denervation. ${ }^{38,39}$ The renal sympathoinhibitory response correlated well with the elevation in the left atrial pressure, and sinoaortic denervation plus vagotomy, but not sinoaortic denervation alone, completely abolished the renal sympathoinhibitory response. ${ }^{38}$ These results indicate that isotonic volume expansion elicits renal sympathoinhibition, which is mainly mediated by the cardiopulmonary receptor with the vagal afferent. This sympathoinhibition has a significant role in augmented renal $\mathrm{Na}^{+}$excretion.

Intravenous hypertonic $\mathrm{NaCl}$ loading also induced renal sympathoinhibition and augmented renal $\mathrm{Na}^{+}$excretion, as did isotonic volume expansion. ${ }^{9}$ However, the afferent pathways of the renal inhibitory responses to these two infusions (hypertonic $\mathrm{NaCl}$ and isotonic solutions) were different. The hypertonic $\mathrm{NaCl}$-induced sympathoinhibitory response was not abolished by sinoaortic denervation plus vagotomy, but was completely abolished by the combination of sinoaortic denervation, vagotomy and hepatic denervation. ${ }^{9}$ Therefore, the hepatic afferent nerves and the hepatorenal reflex have an important role in renal $\mathrm{Na}^{+}$excretion when an excess amount of $\mathrm{NaCl}$ is loaded.

The renal excretory response to salt ingestion is more effective than the response to an equivalent intravenous infusion of saline. This phenomenon is often referred to as 'post-prandial natriuresis. ${ }^{40,41}$ The renal sympathetic nerve may be involved in this natriuresis, because a portal infusion of hypertonic $\mathrm{NaCl}$ solution reduced the renal sympathetic nerve activity, and this reduction was abolished by hepatic denervation. ${ }^{42}$ The role of the liver in controlling renal sympathetic nerve activity and consequently the renal excretory function was more evident in feeding experiments. ${ }^{8}$ In chronically instrumented conscious dogs, $\mathrm{NaCl}$-free food intake did not influence the plasma $\mathrm{Na}^{+}$concentration, renal sympathetic nerve activity or urinary $\mathrm{Na}^{+}$ excretion, whereas high- $\mathrm{NaCl}$ food $\left(0.4 \mathrm{~g} \mathrm{~kg}^{-1}\right.$ body weight $)$ intake increased the plasma $\mathrm{Na}^{+}$concentration by $3.8 \pm 0.7 \mathrm{mmoll}^{-1}$, followed by a $61 \pm 4 \%$ decrease in renal sympathetic nerve activity and increased $\mathrm{Na}^{+}$excretion (Figure 4). In dogs with hepatic denervation, the renal sympathoinhibition seen in the intact dogs in response to
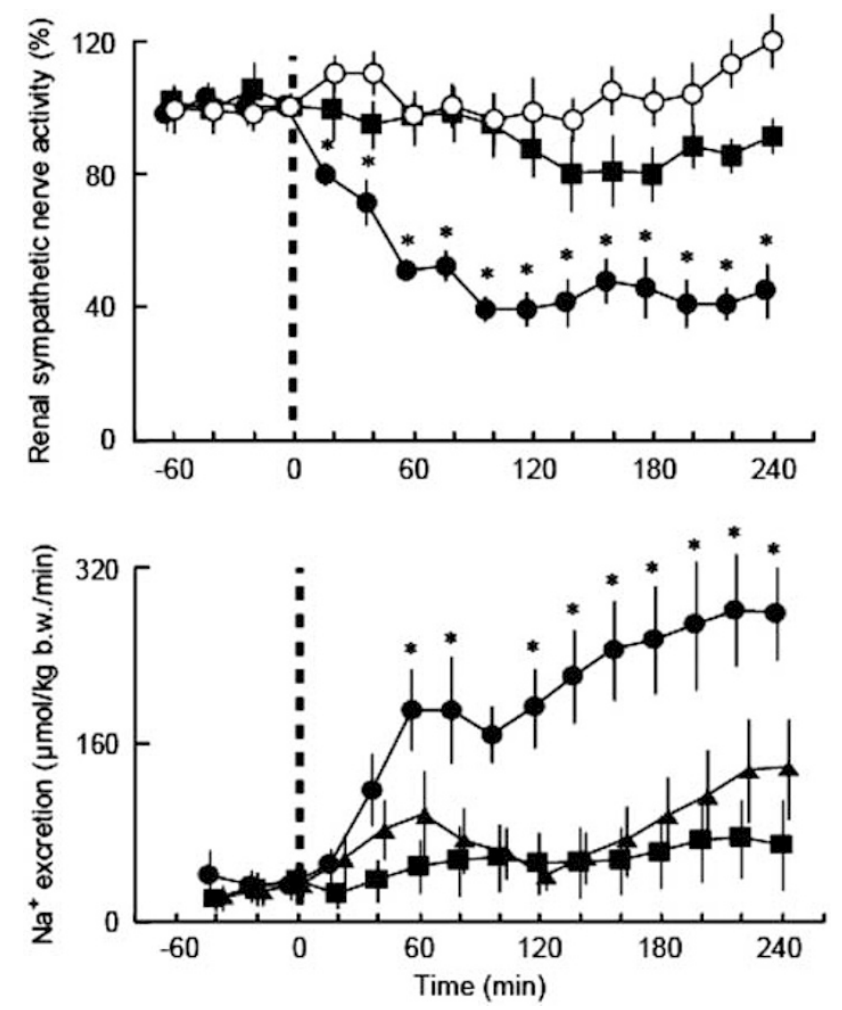

Figure 4 Upper panel: responses of renal sympathetic nerve activity in intact dogs fed a $\mathrm{NaCl}$-free diet (open circles); in intact dogs fed a high$\mathrm{NaCl}$ diet $\left(0.4 \mathrm{~g} \mathrm{~kg}^{-1}\right.$ body weight; closed circles); and in dogs with hepatic denervation fed a high- $\mathrm{NaCl}$ diet (closed squares). Lower panel: urinary $\mathrm{Na}^{+}$ excretion in response to high- $\mathrm{NaCl}$ food intake in intact dogs (closed circles); dogs with hepatic denervation (closed squares); and dogs with renal denervation (closed triangles). Food was given at time 0 . Values are means \pm s.e.m. ${ }^{*} P<0.01$ vs. the pre-feeding control level. Data are modified from (Morita et al. ${ }^{8}$ ).

high- $\mathrm{NaCl}$ food intake was completely abolished, and was accompanied by significantly attenuated post-prandial natriuresis. Only $9 \pm 5 \%$ of the loaded $\mathrm{Na}^{+}$was excreted during 4 consecutive hours in the hepatic-denervated dogs, whereas $36 \pm 5 \%$ of the loaded $\mathrm{Na}^{+}$was excreted in the intact dogs. Therefore, the hepatoportal reflex has an important role in post-prandial natriuresis.

\section{LONG-TERM ROLE FOR HEPATIC NERVES IN NA+ HOMEOSTASIS AND ARTERIAL PRESSURE}

The majority of studies that have investigated the hepatoportal $\mathrm{Na}^{+}$sensitive mechanism have examined the responses to transient or short-term stimulation. Although the data discussed above support the concept of a short-term role for the hepatic nerves in $\mathrm{Na}^{+}$ regulation, few studies have examined the long-term role of the hepatic nerves. To examine this, Wistar-Kyoto rats with or without hepatic denervation were kept in metabolic cages and their $\mathrm{Na}^{+}$ balance was measured continuously for 40 days. ${ }^{43}$ The cumulative $\mathrm{Na}^{+}$balance, calculated from their $\mathrm{Na}^{+}$intake, urinary $\mathrm{Na}^{+}$excretion and fecal $\mathrm{Na}^{+}$excretion, stayed around 0 on a normal $\mathrm{NaCl}$ diet, whereas it became positive on a 3 or $8 \% \mathrm{NaCl}$ diet (Figure $5 \mathrm{a}$ ). Hepatic denervation had no effect on the $\mathrm{Na}^{+}$balance when the rats were fed a $0.45 \% \mathrm{NaCl}$ diet. However, hepatic denervation increased the $\mathrm{Na}^{+}$balance to a greater extent than that observed in shamoperated rats when the rats were fed an $8 \% \mathrm{NaCl}$ diet. At the 

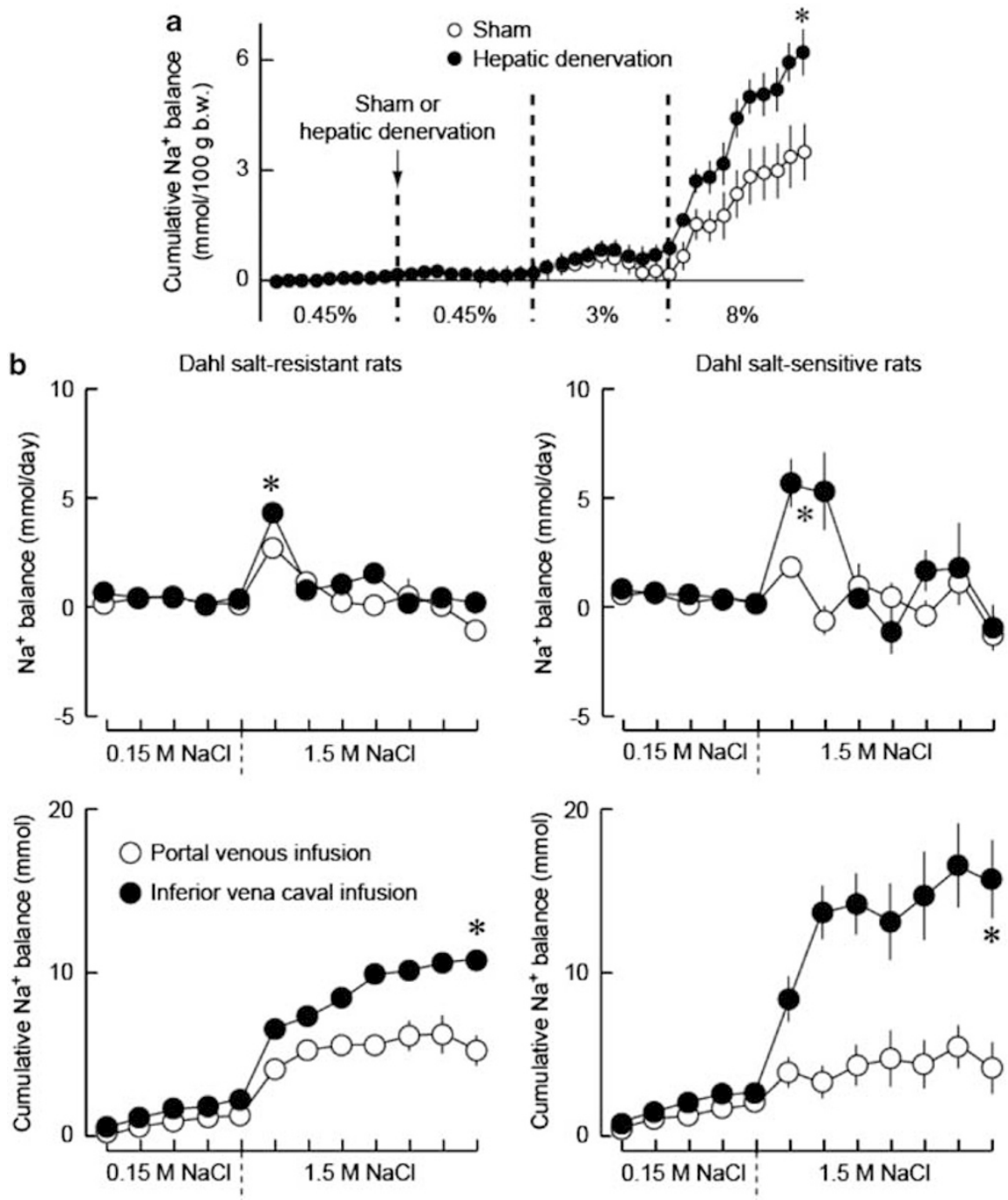

Figure 5 (a) Cumulative $\mathrm{Na}^{+}$balance before and after sham denervation or hepatic denervation in Wistar-Kyoto rats fed a $0.45,3$ or $8 \% \mathrm{NaCl}$ diet. Each diet period was of 10 days duration. ${ }^{*} P<0.05$, the response in hepatic-denervated rats is significantly different from that in sham-operated rats. Modified from (Morita et al. ${ }^{43}$ ). (b) $\mathrm{Na}^{+}$balance and cumulative $\mathrm{Na}^{+}$balance in Dahl salt-resistant (left) and Dahl salt-sensitive rats (right). Normal saline (0.15 $\mathrm{M}$ $\mathrm{NaCl}$ ) was infused $\left(0.5 \mathrm{ml} \mathrm{h}^{-1}\right)$ into the portal vein or inferior vena cava for 5 days and then the solution was changed to $1.5 \mathrm{M} \mathrm{NaCl}$ for 7 days. ${ }^{*} P<0.05$, response after an inferior venous infusion is significantly different from that after a portal venous infusion. Modified from (Morita et al. ${ }^{49}$ ).

conclusion of the metabolic experiments, an arterial catheter was implanted and the arterial pressure was measured 3-5 days after implantation. The mean arterial pressure in the hepatic-denervated rats $(120 \pm 2 \mathrm{~mm} \mathrm{Hg})$ was slightly but significantly higher than that in the sham-operated rats $(108 \pm 3 \mathrm{~mm} \mathrm{Hg})$. These results suggest that hepatic denervation disrupts $\mathrm{Na}^{+}$homeostasis, after which exposure to a high- $\mathrm{NaCl}$ diet exacerbates $\mathrm{Na}^{+}$retention, thereby increasing the arterial pressure. However, it remains unclear whether the observed increase in arterial pressure resulted from hepatic denervation, the high- $\mathrm{NaCl}$ diet or both.

Carlson et al. ${ }^{44}$ used telemetry measurements of arterial pressure to examine the long-term role of the hepatic nerves in controlling the arterial pressure against high- $\mathrm{NaCl}$ challenge. They found that hepatic denervation produced a consistent elevation of the arterial pressure in rats maintained on a normal $\mathrm{NaCl}$ diet $(0.6 \%)$, but that hepatic denervation had little effect on the arterial pressure when WistarKyoto rats were fed $8 \%$ dietary $\mathrm{NaCl}$. Therefore, hepatic denervation itself causes long-term elevation of the mean arterial pressure, but does not appear to appreciably increase the arterial pressure response to a high- $\mathrm{NaCl}$ diet. However, it should be noted that hepaticdenervated animals lose not only the afferent nerves involved in the $\mathrm{Na}^{+}$-sensitive mechanism, but also other afferent nerves, that is those for the baro-, glucose-, amino acid-, and metabolite-sensitive mechanisms and the efferent innervation of the liver. Therefore, hepatic denervation also influences hepatic hemodynamics through changes in the vascular tone of the hepatic artery and portal vein, in the metabolism and in biliary function ${ }^{45-48}$. Therefore, more-selective hepatic denervation or another experimental method that preserves the other hepatic innervation is required. To meet this requirement, $0.15-\mathrm{M} \mathrm{NaCl}$ solution was infused $\left(0.5 \mathrm{ml} \mathrm{h}^{-1}\right)$ into either the portal vein or the inferior vena cave (bypassing the hepatoportal receptors) while the rats were fed low- $\mathrm{NaCl}$ pellets $\left(\mathrm{Na}^{+} 0.0075 \mathrm{mmol} \mathrm{g}^{-1}\right.$ diet $)$, and then $1.5-\mathrm{M} \mathrm{NaCl}$ was infused for 10 days. ${ }^{49}$ Dahl salt-sensitive rats were used in this experiment, because if they retain more $\mathrm{Na}^{+}$and fluid, their arterial pressure may be more highly elevated than in other rats. ${ }^{50}$ The $\mathrm{Na}^{+}$retention induced by a $1.5-\mathrm{M} \mathrm{NaCl}$ infusion was more 
a
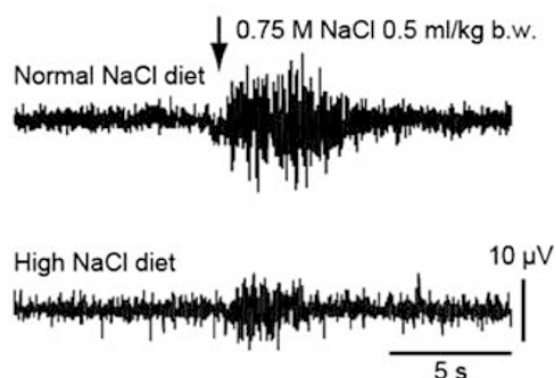

C
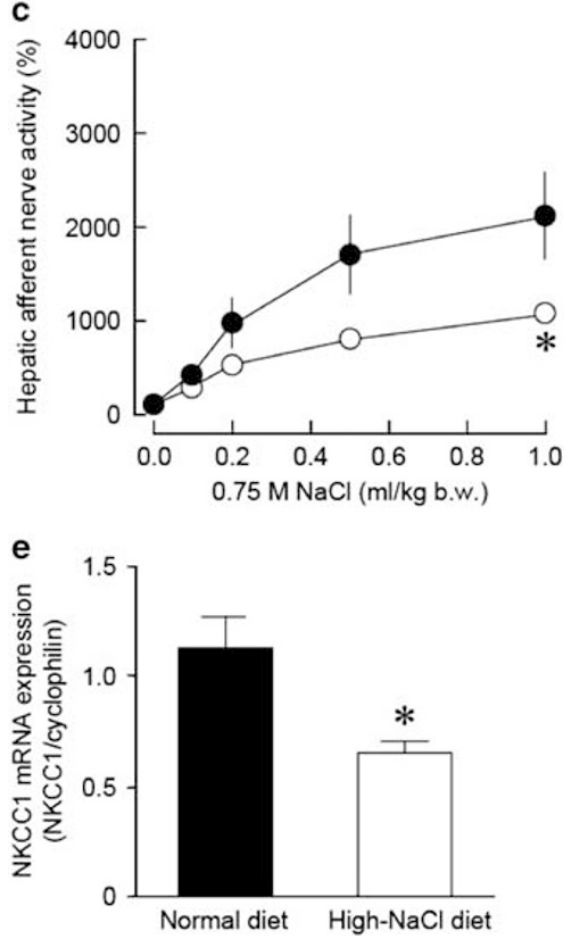

b

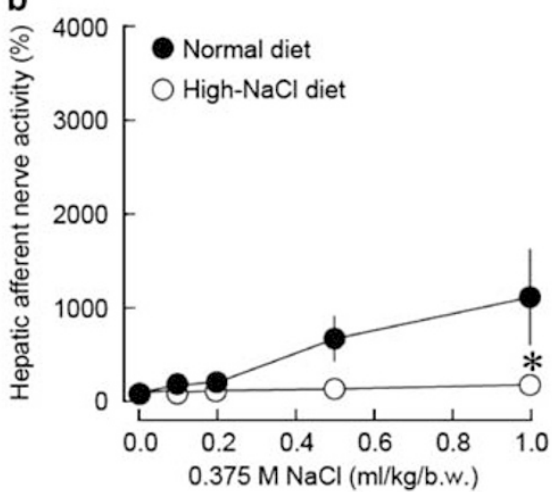

d

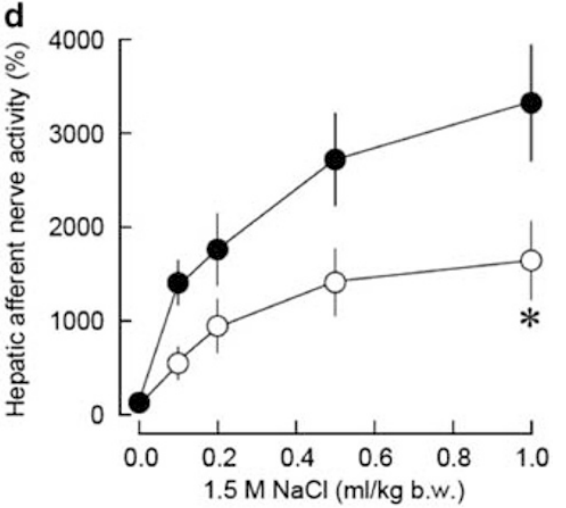

f

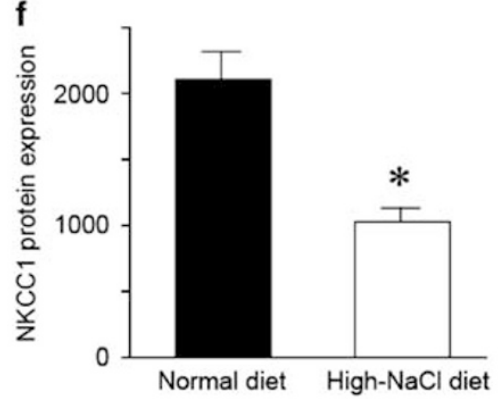

Figure 6 (a) Original records illustrating hepatic afferent nerve activity in response to an intraportal bolus injection of $0.75 \mathrm{M} \mathrm{NaCl}$ (shown by the arrowhead) in a rat on a normal or high- $\mathrm{NaCl}$ diet. (b-d) Summary data showing the responses of hepatic nerve activity to intraportal bolus injections of $0.375,0.75$ or $1.5 \mathrm{M} \mathrm{NaCl}$, respectively. Values are the means \pm s.e.m. for eight rats in each group. ${ }^{*} P<0.05$, significantly different from the normal-diet group. (e) Relative NKCC1/cyclophilin mRNA expression ratio in the livers of rats fed a normal or high-KCl diet. (f) NKCC1 protein expression (expressed in arbitrary intensity units) in the livers of rats fed a normal or high- $\mathrm{NaCl}$ diet. Values are the means $\pm \mathrm{SE}$ for eight rats in each group. ${ }^{*} P<0.05$, significantly different from the normal-diet group. Modified from (Tsuchiya et al. ${ }^{54}$ ).

obvious in the inferior vena cava group than in the portal vein group, and this trend was more obvious in the Dahl salt-sensitive rats than in the Dahl salt-resistant rats (Figure 5b). This effect was only apparent for 2 days, but this positive balance was not compensated in subsequent days. Furthermore, the mean arterial pressure in the inferior vena cava group $(150 \pm 3 \mathrm{~mm} \mathrm{Hg})$ was significantly higher than that in the portal vein group $(138 \pm 1 \mathrm{~mm} \mathrm{Hg})$ in the Dahl saltsensitive strain. However, in the Dahl salt-resistant rats, the mean arterial pressure did not differ between the inferior vena cava group $(119 \pm 3 \mathrm{~mm} \mathrm{Hg})$ and the portal vein group $(112 \pm 2 \mathrm{~mm} \mathrm{Hg})$. These results suggest that the hepatic $\mathrm{Na}^{+}$-sensitive mechanism has a significant role in controlling $\mathrm{Na}^{+}$homeostasis when animals are challenged with high $\mathrm{NaCl}$. Although this effect is only transient $(\sim 2$ days), the resultant positive balance is not compensated thereafter.
Because a high- $\mathrm{NaCl}$ diet affects the expression, distribution and phosphorylation status of $\mathrm{Na}^{+}$transporters or channels in the kidney and intestine, ${ }^{51-53}$ the fact that the hepatic $\mathrm{Na}^{+}$-sensitive mechanism is only transiently significant in $\mathrm{Na}^{+}$homeostasis implies a desensitization or downregulation of the hepatic $\mathrm{Na}^{+}$receptor, NKCC1. To test this hypothesis, the expression of NKCC1 mRNA and protein and the sensitivity of the hepatic $\mathrm{Na}^{+}$receptor were examined after 4 weeks on a high- $\mathrm{NaCl}$ diet. ${ }^{54}$ Orally ingested $\mathrm{Na}^{+}$is absorbed from the intestine into the blood, circulates in the hepatic vasculature and then enters the systemic circulation. Therefore, during the long-term intake of a high- $\mathrm{NaCl}$ diet, the hepatoportal $\mathrm{Na}^{+}$receptor may be continuously exposed to high concentrations of $\mathrm{Na}^{+}$. The response of hepatic afferent nerve activity to an intraportal injection of hypertonic $\mathrm{NaCl}$ solution was suppressed by a high- $\mathrm{NaCl}$ diet (Figures $6 \mathrm{a}-\mathrm{d}$ ). This was 
accompanied by the significantly reduced expression of NKCC1 mRNA and protein in the liver (Figures 6e and f). The high-NaCldiet-induced reduction in the sensitivity of the hepatic $\mathrm{Na}^{+}$receptor is consistent with the observation that this receptor has a significant role in controlling $\mathrm{Na}^{+}$homeostasis only in the short-term, but not in the long-term. In other words, the reduced sensitivity of the hepatic $\mathrm{Na}^{+}$ receptor reduces the role of the hepatic $\mathrm{Na}^{+}$-sensitive mechanism in the long-term control of $\mathrm{Na}^{+}$homeostasis.

\section{LIVER CIRRHOSIS}

Renal sodium and water retention and the development of edema are the common symptoms of liver cirrhosis, and the natriuretic response to saline infusion is less pronounced in cirrhotic patients. ${ }^{55}$ The elevated renal venous noradrenaline concentration in cirrhotic patients ${ }^{56-58}$ suggests that augmented renal sympathetic nerve activity is a mechanism underlying the abnormal body fluid regulation in liver cirrhosis. This increase has the capacity to alter renal function by altering tubular reabsorption, renin release and renal hemodynamics, in a manner consistent with the phenomena observed in cirrhosis. In fact, a unilateral lumbar sympathetic block induces significant increases in the glomerular filtration rate, osmolal clearance, urinary $\mathrm{Na}^{+}$excretion, fractional excretion of filtered $\mathrm{Na}^{+}$, and effective renal plasma flow and a reduction in plasma renin activity in patients with cirrhosis. ${ }^{59}$ In an animal model of liver cirrhosis, more-specific renal denervation can be achieved and it has been demonstrated that bilateral renal denervation attenuates the progressive renal $\mathrm{Na}^{+}$retention that occurs in rats with cirrhosis induced by common bile duct ligation. ${ }^{60}$ In that study, the cirrhotic rats retained $4.05 \mathrm{mmol} \mathrm{Na}^{+}$at the end of 1 week on a normal $\mathrm{Na}^{+}$diet plus 2 weeks on a low- $\mathrm{Na}^{+}$ diet. This value was significantly greater than that recorded for sham-treated rats $(1.53 \mathrm{mmol})$. In cirrhotic rats with bilateral renal denervation, $\mathrm{Na}^{+}$retention was significantly ameliorated $(2.61 \mathrm{mmol})$. Therefore, $2.52 \mathrm{mmol}$ more $\mathrm{Na}^{+}$was retained in cirrhotic rats than in sham-treated rats, and the augmented renal sympathetic nerve activity was responsible for approximately $57 \%$ of the $\mathrm{Na}^{+}$retention in the cirrhotic rats.

When studying the plasma catecholamine and central hemodynamics of cirrhotic patients, Henriksen et al. ${ }^{61}$ reported that plasma noradrenaline correlated positively with the wedged hepatic vein pressure, but inversely with the plasma volume. Two possible factors were suggested as responsible for the increased renal sympathetic nerve activity in liver cirrhosis: the central blood volume and the portal pressure. Cirrhotic patients exhibit characteristic hemodynamic changes, with a hyperkinetic circulation and an abnormal distribution of the blood volume. The central blood volume decreases, despite an increase in the non-central blood volume. ${ }^{62}$ Therefore, it is possible that the cardiopulmonary volume receptor is unloaded, and the renal sympathetic nerve is then reflexively activated. ${ }^{63}$ Consistent with this, an increase in the central blood volume with no effect on the total blood volume, induced by head-out water immersion, which is known to reduce renal sympathetic nerve activity via the cardiopulmonary volume receptor, ${ }^{64,65}$ significantly improves the renal excretory function. ${ }^{66}$

Increased hepatic portal pressure is the other factor responsible for the increased renal sympathetic nerve activity. Andrews and Palmer ${ }^{67}$ were the first to record afferent discharges from hepatic baroreceptors. They showed that hepatic venous congestion induced by thoracic vena cava occlusion stimulated the hepatic baroreceptors and increased hepatic afferent nerve activity, whereas occlusion of the hepatic artery had no effect. When the hepatic baroreceptors were stimulated by increasing the portal pressure from 6 to $20 \mathrm{~mm} \mathrm{Hg}$, the glomerular filtration rate and renal blood flow decreased, and renin secretion increased, although the renal perfusion pressure remained constant. ${ }^{68}$ These changes were abolished by renal denervation. Stronger evidence for the hepatorenal baroreflex was provided by Kostreva et al. ${ }^{3}$ who found that increasing the intrahepatic sinusoidal pressure increased the hepatic afferent nerve activity and renal sympathetic nerve activity. Although relatively few studies have evaluated this pathway in cirrhotic patients, improved renal function and lowered noradrenaline overflow from the kidney have been observed when the intrahepatic pressure is reduced in cirrhotic patients. ${ }^{69,70}$ These observations are consistent with the notion that the hepatoportal baroreflex contributes to increased renal sympathetic nerve activity.

In addition to the stimulation of the hepatoportal baroreflex, cirrhosis might also affect the hepatoportal $\mathrm{Na}^{+}$-sensitive mechanisms. Lopez-Novoa and Martinez-Maldonado ${ }^{71}$ demonstrated that the natriuretic response to the portal infusion of hypertonic $\mathrm{NaCl}$ solution is impaired in rats with liver cirrhosis. Stronger evidence for impaired hepatic $\mathrm{Na}^{+}$-sensitive mechanisms was reported by Tanaka et al. ${ }^{72}$ who found that the response of hepatic afferent nerve activity to an intraportal injection of hypertonic $\mathrm{NaCl}$ solution was suppressed in rats with carbon terrachloride $\left(\mathrm{CCl}_{4}\right)$-induced cirrhosis (Figure 7 ). Metabolic experiments revealed that there was no difference in the cumulative $\mathrm{Na}^{+}$balance (cumulative $\mathrm{Na}^{+}$intake minus cumulative
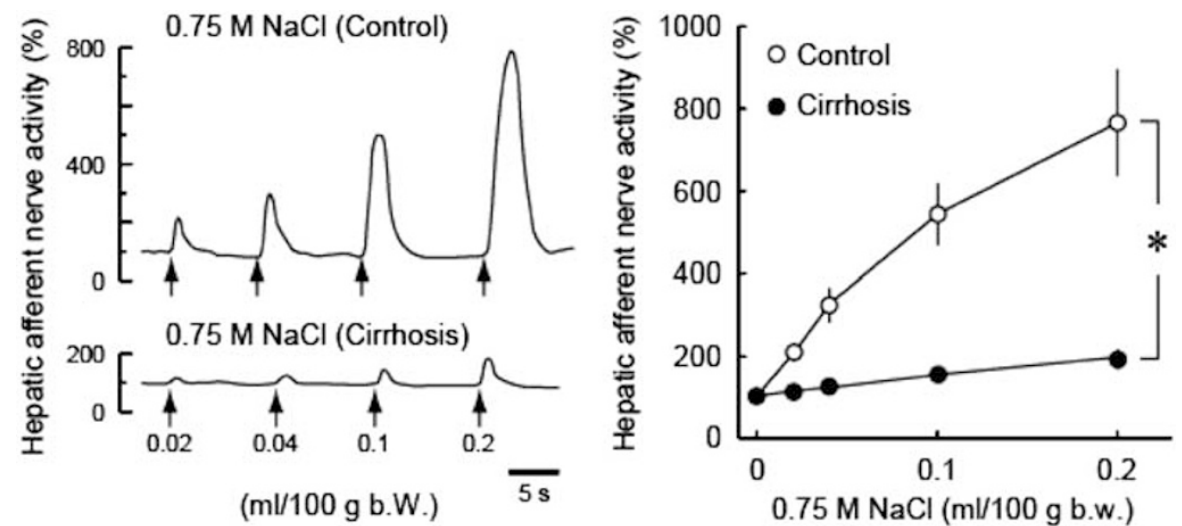

Figure 7 Left panel: typical records illustrating the response of the mean hepatic afferent nerve activity to a portal injection of $0.75 \mathrm{~m} N \mathrm{NaCl}$ solution. Right panel: hepatic afferent nerve activity in response to a portal injection of $0.75 \mathrm{M} \mathrm{NaCl}$ in control rats and in rats with $\mathrm{CCl}_{4}$-induced liver cirrhosis. Values means \pm s.e.m. ${ }^{*} P<0.01$, significantly different from the control rats. Modified from (Tanaka et al. ${ }^{72}$ ). 

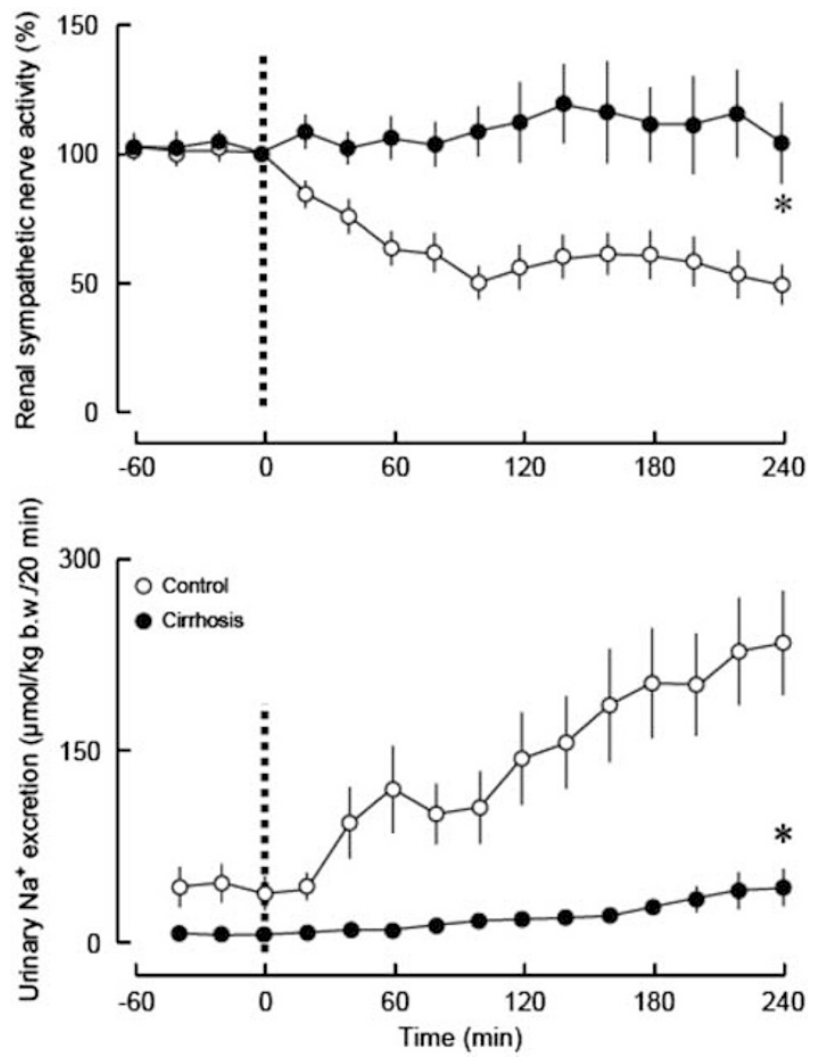

Figure 8 Responses of renal sympathetic nerve activity and urinary $\mathrm{Na}^{+}$ excretion to high- $\mathrm{NaCl}$ food intake $\left(20 \mathrm{~g} \mathrm{~kg}^{-1}\right.$ boiled rice containing $0.4 \mathrm{~g} \mathrm{~kg}^{-1}$ body weight $\mathrm{NaCl}$ ) given at time 0 . Control: sham-operated control dogs. Cirrhosis: dogs with chronic cirrhosis induced by bile-duct ligation. Values are means \pm s.e.m. ${ }^{*} P<0.05$, the responses in the cirrhotic dogs are significantly different from those in the control dogs. Modified from (Matsuda et al. ${ }^{73}$ ).
$\mathrm{Na}^{+}$excretion) if the cirrhotic rats were fed a normal $\mathrm{NaCl}(0.45 \%)$ diet. However, if they were fed an $8 \% \mathrm{NaCl}$ diet, significantly more $\mathrm{Na}^{+}$accumulated in the cirrhotic rats. ${ }^{72}$ Because the acute $\mathrm{Na}^{+}$ excretory response to high- $\mathrm{NaCl}$ food intake is completely mediated by the hepatorenal reflex evoked by the hepatoportal $\mathrm{Na}^{+}$-sensitive mechanism, ${ }^{8}$ this reflex might be impaired in liver cirrhosis. This was confirmed in a feeding experiment in which conscious dogs were fed high- $\mathrm{NaCl}$ food $\left(20 \mathrm{~g} \mathrm{~kg}^{-1}\right.$ body weight boiled rice containing $0.4 \mathrm{~g} \mathrm{~kg}^{-1}$ body weight $\mathrm{NaCl}$ ) and their renal sympathetic nerve activity and urinary $\mathrm{Na}^{+}$excretion were measured. ${ }^{73}$ In sham-operated control dogs, the renal sympathetic nerve activity decreased by $50 \%$ $100 \mathrm{~min}$ after feeding and remained at the same level until $4 \mathrm{~h}$ after feeding (Figure 8). Urinary $\mathrm{Na}^{+}$excretion increased gradually and $27 \%$ of the loaded $\mathrm{Na}^{+}$was excreted in 4 consecutive hours. However, the reduction in renal sympathetic nerve activity seen in the control dogs was completely abolished in dogs with cirrhosis induced by bile-duct ligation, and only $4 \%$ of the loaded $\mathrm{Na}^{+}$was excreted in the 4 consecutive hours after feeding. Therefore, the attenuated post-prandial natriuresis seen in the cirrhotic dogs may be attributable to the lack of the renal sympathetic nerve activity response, because postprandial natriuresis is mainly mediated by a reduction in renal sympathetic nerve activity, as an efferent pathway. ${ }^{8}$

A possible explanation for the impaired hepatorenal reflex is that the function of the hepatic $\mathrm{Na}^{+}$receptor or intrahepatic afferent limb is impaired in cirrhosis, because cirrhosis disrupts the normal hepatic architecture, with the appearance of fibrotic bands linking portal triads and nodular regeneration. Immunohistochemical studies have shown that the nerve fibers in the liver parenchyma are reduced or nearly completely absent in cirrhotic liver disease, whereas the nerve fibers in the portal tracts and fibrous septae remain prominent. ${ }^{74-76}$ These observations are consistent with an impaired $\mathrm{Na}^{+}$-sensitive hepatorenal reflex, but are not consistent with hepatorenal-baroreflex-induced excitation of renal sympathetic nerve activity, because

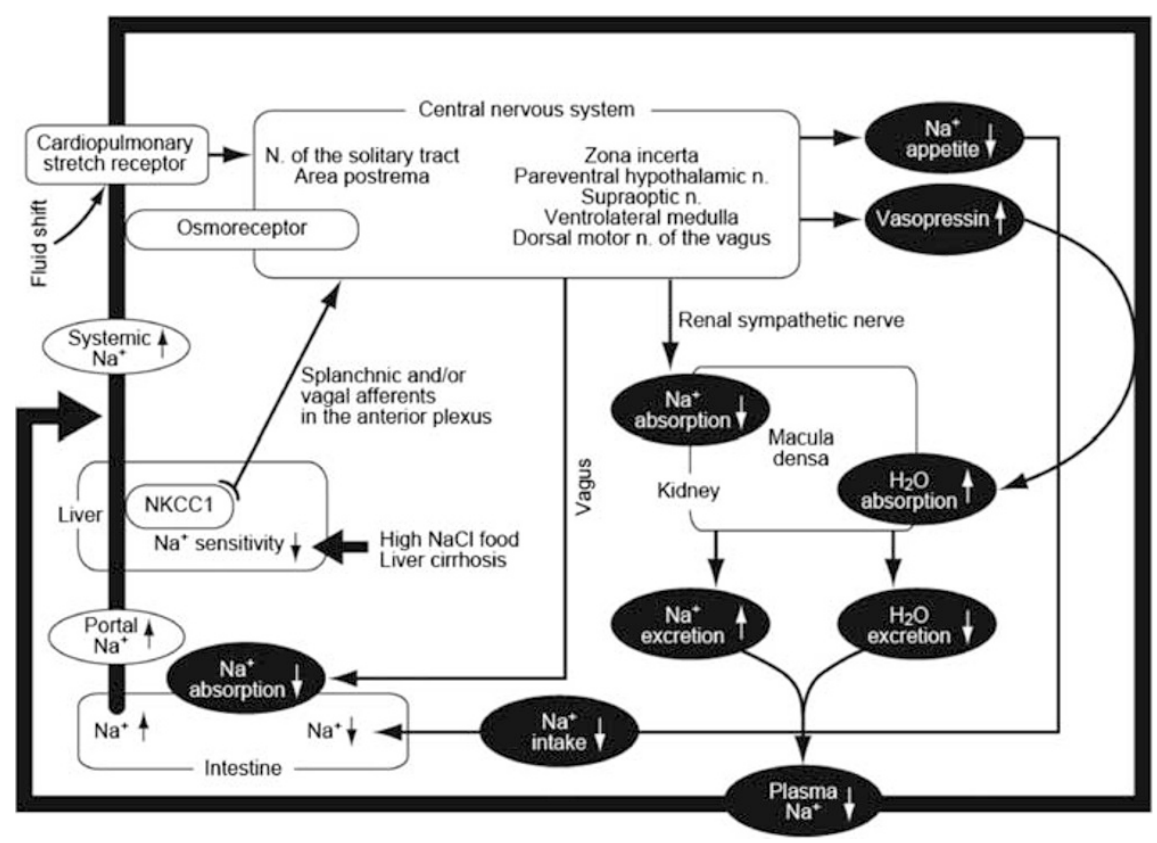

Figure 9 Schematic representation of the mechanisms involved in $\mathrm{Na}^{+}$homeostasis. The negative feedback systems and the hepatoportal $\mathrm{Na}^{+}$sensitive mechanism cooperate to regulate plasma $\mathrm{Na}^{+}$concentration. They may share common central and efferent pathways mediating salt appetite, intestinal absorptive function and renal excretory function. The thick line represents plasma flow from the portal vein to the systemic circulation. 
reduced hepatic innervation might impair this reflex. If so, renal sympathoexcitation might not be induced. However, the increase in intrahepatic sinusoidal pressure caused by constriction of the thoracic inferior vena cava induced increases in hepatic afferent nerve activity and renal sympathetic nerve activity in both sham and cirrhotic rats. The slope gain, calculated as the percentage increase in hepatic afferent nerve activity divided by the increase in pressure, did not differ between the sham and cirrhotic rats. ${ }^{77}$ Therefore, the hepatorenal baroreflex is even preserved well in liver cirrhosis, in which hepatic innervation is markedly impaired.

\section{CONCLUDING REMARKS}

$\mathrm{Na}^{+}$homeostasis is generally explained by negative feedback systems triggered by cardiopulmonary stretch receptors, $\mathrm{Na}^{+}$receptors in the macula densa and central osmoreceptors. Stimulation of these receptors reflexively alter salt appetite, intestinal absorptive function and renal excretory function; then changes in plasma $\mathrm{Na}^{+}$concentration are corrected (Figure 9). In this article, we have reviewed a second major $\mathrm{Na}^{+}$control system found in the hepatoportal region. Although the hepatoportal $\mathrm{Na}^{+}$-sensitive mechanism also regulates salt appetite ${ }^{49,78}$ and intestinal absorptive function, ${ }^{10,79}$ this review focused on renal excretory function, that is, the hepatoportal reflex. The portal venous $\mathrm{Na}^{+}$concentration changes in advance of the $\mathrm{Na}^{+}$concentration in the systemic circulation. The hepatorenal reflex is triggered by the increase in the $\mathrm{Na}^{+}$concentration in the portal vein, and then controls the $\mathrm{Na}^{+}$concentration in the systemic blood. These observations introduce the interesting concept of negative feedforward or prospective control, that is, the $\mathrm{Na}^{+}$control system is activated before the composition of the systemic blood is altered.

The $\mathrm{Na}^{+}$-sensitive hepatorenal reflex has a significant role in postprandial natriuresis. The increase in the $\mathrm{Na}^{+}$concentration in the portal blood is transduced into an increase in hepatic afferent nerve activity. This afferent signal is sent to the osmoregulatory center, and then renal sympathetic nerve activity is suppressed reflexively. However, the long-term role of this reflex in $\mathrm{Na}^{+}$homeostasis may be less important, probably because of the desensitization of $\mathrm{Na}^{+}$-sensitive mechanisms, which occurs if the hepatoportal region is exposed to high $\mathrm{Na}^{+}$concentrations for a long time. NKCC1 is involved in the hepatoportal $\mathrm{Na}^{+}$-sensitive mechanism, and NKCC1 expression is reduced by a high- $\mathrm{NaCl}$ diet. This observation may explain the desensitization of the $\mathrm{Na}^{+}$-sensitive hepatorenal reflex. Liver cirrhosis impairs the $\mathrm{Na}^{+}$-sensitive hepatorenal reflex, whereas hepatoportal baroreflex is preserved well in liver cirrhosis. Hepatoportal baroreceptor-induced renal sympathetic excitation and the impaired $\mathrm{Na}^{+}$sensitive hepatorenal reflex may partially explain the $\mathrm{Na}^{+}$retention in liver cirrhosis.

1 Adachi A, Niijima A, Jacobs HL. An hepatic osmoreceptor mechanism in the rat: electrophysiological and behavioral studies. Am J Physiol 1976; 231: 1043-1049.

2 Niijima A. Afferent discharges from osmoreceptors in the liver of the guinea pig. Science 1969; 166: 1519-1520.

3 Kostreva DR, Castaner A, Kampine JP. Reflex effects of hepatic baroreceptors on renal and cardiac sympathetic nerve activity. Am J Physiol 1980; 238: R390-R394.

4 Lang F, Tschernko E, Schulze E, Ottl I, Ritter M, Völkl H, Hallbrucker C, Häussinger D. Hepatorenal reflex regulating kidney function. Hepatology 1991; 14(4 Part 1): 590-594.

5 Andrews WH, Orbach J. Sodium receptors activating some nerves of perfused rabbit livers. Am J Physiol 1974; 227: 1273-1275.

6 Morita H, Fujiki N, Hagiike M, Yamaguchi O, Lee K. Functional evidence for involvement of bumetanide-sensitive $\mathrm{Na}^{+} \mathrm{K}^{+} 2 \mathrm{Cl}^{-}$cotransport in the hepatoportal $\mathrm{Na}+$ receptor of the Sprague-Dawley rat. Neurosci Lett 1999; 264: 65-68.
7 Morita H, Fujiki N, Miyahara T, Lee K, Tanaka K. Hepatoportal bumetanide-sensitive $\mathrm{K}(+)$-sensor mechanism controls urinary $\mathrm{K}(+)$ excretion. Am J Physiol Regul Integr Comp Physiol 2000; 278: R1134-R1139.

8 Morita H, Matsuda T, Furuya F, Khanchowdhury MR, Hosomi H. Hepatorenal reflex plays an important role in natriuresis after high- $\mathrm{NaCl}$ food intake in conscious dogs. Circ Res 1993; 72: 552-559.

9 Morita H, Nishida Y, Hosomi H. Neural control of urinary sodium excretion during hypertonic $\mathrm{NaCl}$ load in conscious rabbits: role of renal and hepatic nerves and baroreceptors. J Auton Nerv Syst 1991; 34: 157-169.

10 Morita H, Ohyama H, Hagiike M, Horiba T, Miyake K, Yamanouchi H, Matsushita K, Hosomi $H$. Effects of portal infusion of hypertonic solution on jejunal electrolyte transport in anesthetized dogs. Am J Physiol 1990; 259(6 Part 2): R1289-R1294.

11 Haberich FJ, Aziz O, Nowacki PE. [On an osmoreceptor active mechanism in the liver]. Pflugers Arch Gesamte Physiol Menschen Tiere 1965; 285: 73-89.

12 Haberich FJ. Osmoreception in the portal circulation. Fed Proc 1968; 27: 1137-1141.

13 Andrews WH, Orbach J. Effect of osmotic pressure on spontaneous afferent discharge in the nerves of the perfused rabbit liver. Pflugers Arch 1975; 361: 89-94.

14 Andrews WH, Stratmann CJ. Afferent nervous impulses in the hepatic nerve of perfused rabbit livers. J Physiol 1968; 195: 32P-33P.

15 Kuntz A. The Autonomic Nervous System. Lea \& Febiger: Philadelphia, 1953.

16 Pick J. The Autonomic Nervous System: Morphological, Comparative, Clinical and Surgical Aspect. JB Lippincott Company: Philadelphia/Toronto, 1970.

17 Berthoud HR, Kressel M, Neuhuber WL. An anterograde tracing study of the vagal innervation of rat liver, portal vein and biliary system. Anat Embryol (Berl) 1992; 186: 431-442.

18 Berthoud HR. Anatomy and function of sensory hepatic nerves. Anat Rec A Discov Mol Cell Evol Biol 2004; 280: 827-835.

19 Morita H, Yamashita Y, Nishida Y, Tokuda M, Hatase O, Hosomi H. Fos induction in rat brain neurons after stimulation of the hepatoportal Na-sensitive mechanism. Am J Physiol 1997; 272(3 Part 2): R913-R923.

20 Lapointe JY, Bell PD, Cardinal J. Direct evidence for apical $\mathrm{Na}+2 \mathrm{Cl}-: \mathrm{K}+$ cotransport in macula densa cells. Am J Physiol 1990; 258(5 Part 2): F1466-F1469.

21 Lindemann B. Taste reception. Physiol Rev 1996; 76: 718-766.

22 Schlatter E. Effect of various diuretics on membrane voltage of macula densa cells. Whole-cell patch-clamp experiments. Pflugers Arch 1993; 423: 74-77.

23 Schlatter E, Salomonsson M, Persson AE, Greger R. Macula densa cells sense luminal $\mathrm{NaCl}$ concentration via furosemide sensitive $\mathrm{Na}+2 \mathrm{Cl}-\mathrm{K}+$ cotransport. Pflugers Arch 1989; 414: 286-290.

24 Renner EL, Lake JR, Scharschmidt BF, Zimmerli B, Meier PJ. Rat hepatocytes exhibit basolateral Na+/HCO3- cotransport. J Clin Invest 1989; 83: 1225-1235.

25 Graf J, Haussinger D. Ion transport in hepatocytes: mechanisms and correlations to cell volume, hormone actions and metabolism. J Hepatol 1996; 24(Suppl 1): 53-77.

26 Vom Dahl S, Haussinger D. Bumetanide-sensitive cell swelling mediates the inhibitory effect of ethanol on proteolysis in rat liver. Gastroenterology 1998; 114: 1046-1053.

27 Kobashi M, Adachi A. Convergence of hepatic osmoreceptive inputs on sodiumresponsive units within the nucleus of the solitary tract of the rat. $J$ Neurophysiol 1985; 54: 212-219.

28 Kobashi M, Adachi A. Projection of nucleus tractus solitarius units influenced by hepatoportal afferent signal to parabrachial nucleus. J Auton Nerv Syst 1986; 16: 153-158.

29 Kobashi M, Adachi A. A hepatoportal osmoreceptive afferent projection from nucleus tractus solitarius to caudal ventrolateral medulla. Brain Res Bull 1990; 24: 775-778.

30 Schmitt M. Influences of hepatic portal receptors on hypothalamic feeding and satiety centers. Am J Physiol 1973; 225: 1089-1095.

31 Carlson SH, Beitz A, Osborn JW. Intragastric hypertonic saline increases vasopressin and central Fos immunoreactivity in conscious rats. Am J Physiol 1997; 272(3 Part 2): R750-R758.

32 Carlson SH, Osborn JW. Splanchnic and vagal denervation attenuate central Fos but not AVP responses to intragastric salt in rats. Am J Physiol 1998; 274(5 Part 2): R1243-R1252.

33 Choi-Kwon S, Baertschi AJ. Splanchnic osmosensation and vasopressin: mechanisms and neural pathways. Am J Physiol 1991; 261(1 Part 1): E18-E25.

34 Baertschi AJ, Vallet PG. Osmosensitivity of the hepatic portal vein area and vasopressin release in rats. J Physiol 1981; 315: 217-230.

35 Vallet PG, Baertschi AJ. Spinal afferents for peripheral osmoreceptors in the rat. Brain Res 1982; 239: 271-274.

36 Barajas L, Liu L, Powers K. Anatomy of the renal innervation: intrarenal aspects and ganglia of origin. Can J Physiol Pharmacol 1992; 70: 735-749.

37 DiBona GF, Kopp UC. Neural control of renal function. Physiol Rev 1997; 77: 75-197.

38 Morita $\mathrm{H}$, Vatner SF. Effects of volume expansion on renal nerve activity, renal blood flow, and sodium and water excretion in conscious dogs. Am J Physiol 1985; 249(5 Part 2): F680-F687.

39 DiBona GF, Sawin LL. Renal nerve activity in conscious rats during volume expansion and depletion. Am J Physiol 1985; 248(1 Part 2): F15-F23.

40 Singer DR, Markandu ND, Buckley MG, Miller MA, Sagnella GA, MacGregor GA. Contrasting endocrine responses to acute oral compared with intravenous sodium loading in normal humans. Am J Physiol 1998; 274(1 Part 2): F111-F119.

41 Carey RM, Smith JR, Ortt EM. Gastrointestinal control of sodium excretion in sodiumdepleted conscious rabbits. Am J Physiol 1976; 230: 1504-1508.

42 Morita $\mathrm{H}$, Ishiki K, Hosomi $\mathrm{H}$. Effects of hepatic $\mathrm{NaCl}$ receptor stimulation on renal nerve activity in conscious rabbits. Neurosci Lett 1991; 123: 1-3.

43 Morita $\mathrm{H}$, Chen $\mathrm{Q}$, Hosomi $\mathrm{H}$. Role of hepatic nerves in long-term control of $\mathrm{NaCl}$ homeostasis in Wistar-Kyoto rats. J Auton Nerv Syst 1995; 54: 9-15. 
44 Carlson SH, Osborn JW, Wyss JM. Hepatic denervation chronically elevates arterial pressure in Wistar-Kyoto rats. Hypertension 1998; 32: 46-51.

45 McCuskey RS. Anatomy of efferent hepatic nerves. Anat Rec A Discov Mol Cell Evol Biol 2004; 280: 821-826.

46 Niijima A, Meguid MM. An electrophysiological study on amino acid sensors in the hepato-portal system in the rat. Obes Res 1995; 3(Suppl 5): 741S-745S

47 Warne JP, Foster MT, Horneman HF, Pecoraro NC, Ginsberg AB, Akana SF, Dallman MF. Afferent signalling through the common hepatic branch of the vagus inhibits voluntary lard intake and modifies plasma metabolite levels in rats. J Physiol 2007; 583(Part 2): 455-467.

48 Yi CX, la Fleur SE, Fliers E, Kalsbeek A. The role of the autonomic nervous liver innervation in the control of energy metabolism. Biochim Biophys Acta 2010; 1802 : 416-431.

49 Morita H, Tsunooka K, Hagiike M, Yamaguchi O, Lee K. Role of the liver in long-term control of drinking behavior, $\mathrm{Na}+$ balance, and arterial pressure in Dahl rats. $\mathrm{Am} \mathrm{J}$ Physiol 1998; 274(4 Part 2): R1111-R1118.

50 Greene AS, Yu ZY, Roman RJ, Cowley Jr AW. Role of blood volume expansion in Dahl rat model of hypertension. Am J Physiol 1990; 258(2 Part 2): H508-H514.

51 Stokes JB, Sigmund RD. Regulation of rENaC mRNA by dietary $\mathrm{NaCl}$ and steroids: organ, tissue, and steroid heterogeneity. Am J Physiol 1998; 274(6 Part 1): C1699-C1707.

52 Vallon V, Schroth J, Lang F, Kuhl D, Uchida S. Expression and phosphorylation of the $\mathrm{Na}^{+}-\mathrm{Cl}^{-}$cotransporter NCC in vivo is regulated by dietary salt, potassium, and SGK1. Am J Physiol Renal Physiol 2009; 297: F704-F712.

53 Yang LE, Sandberg MB, Can AD, Pihakaski-Maunsbach K, McDonough AA. Effects of dietary salt on renal $\mathrm{Na}+$ transporter subcellular distribution, abundance, and phosphorylation status. Am J Physiol Renal Physiol 2008; 295: F1003-F1016.

54 Tsuchiya Y, Nakashima S, Banno Y, Suzuki Y, Morita H. Effect of high- $\mathrm{NaCl}$ or high-KCl diet on hepatic $\mathrm{Na}^{+}$- and $\mathrm{K}^{+}$-receptor sensitivity and $\mathrm{NKCC} 1$ expression in rats. $\mathrm{Am} \mathrm{J}$ Physiol Regul Integr Comp Physiol 2004; 286: R591-R596.

55 Wood LJ, Massie D, McLean AJ, Dudley FJ. Renal sodium retention in cirrhosis: tubular site and relation to hepatic dysfunction. Hepatology 1988; 8: 831-836.

56 Bendtsen F, Christensen NJ, Sorensen TI, Henriksen JH. Effect of oral propranolol administration on azygos, renal and hepatic uptake and output of catecholamines in cirrhosis. Hepatology 1991; 14: 237-243.

57 Henriksen JH, Ring-Larsen H, Kanstrup IL, Christensen NJ. Splanchnic and renal elimination and release of catecholamines in cirrhosis. Evidence of enhanced sympathetic nervous activity in patients with decompensated cirrhosis. Gut 1984; 25: 1034-1043.

58 Willett I, Esler M, Burke F, Leonard P, Dudley F. Total and renal sympathetic nervous system activity in alcoholic cirrhosis. J Hepatol 1985; 1: 639-648.

59 Solis-Herruzo JA, Duran A, Favela V, Castellano G, Madrid JL, Muñoz-Yagüe MT, Morillas JD, Estenoz J. Effects of lumbar sympathetic block on kidney function in cirrhotic patients with hepatorenal syndrome. J Hepatol 1987; 5: 167-173.

60 DiBona GF, Sawin LL. Role of renal nerves in sodium retention of cirrhosis and congestive heart failure. Am J Physiol 1991; 260(2 Part 2): R298-R305.

61 Henriksen JH, Christensen NJ, Ring-Larsen H. Noradrenaline and adrenaline concentrations in various vascular beds in patients with cirrhosis. Relation to haemodynamics. Clin Physiol 1981; 1: 293-304.
62 Moller S, Henriksen JH. Circulatory abnormalities in cirrhosis with focus on neurohumoral aspects. Semin Nephrol 1997; 17: 505-519.

63 Morita H, Vatner SF. Effects of hemorrhage on renal nerve activity in conscious dogs. Circ Res 1985; 57: 788-793.

64 Miki K, Hayashida Y, Sagawa S, Shiraki K. Renal sympathetic nerve activity and natriuresis during water immersion in conscious dogs. Am J Physiol 1989; 256(2 Part 2): R299-R305.

65 Miki K, Hayashida Y, Shiraki K. Role of cardiac-renal neural reflex in regulating sodium excretion during water immersion in conscious dogs. J Physiol 2002; 545(Part 1): 305-312.

66 Epstein M, Larios O, Johnson G. Effects of water immersion on plasma catecholamines in decompensated cirrhosis. Implications for deranged sodium and water homeostasis. Miner Electrolyte Metab 1985; 11: 25-34.

67 Andrews WH, Palmer JF. Afferent nervous discharge from the canine liver. $Q \mathrm{~J}$ Exp Physiol Cogn Med Sci 1967; 52: 269-276.

68 Anderson RJ, Cronin RE, McDonald KM, Schrier RW. Mechanisms of portal hypertension-induced alterations in renal hemodynamics, renal water excretion, and renin secretion. J Clin Invest 1976; 58: 964-970.

69 Stadlbauer V, Wright GA, Banaji M, Mukhopadhya A, Mookerjee RP, Moore K, Jalan R. Relationship between activation of the sympathetic nervous system and renal blood flow autoregulation in cirrhosis. Gastroenterology 2008; 134: 111-119.

70 Esler M, Dudley F, Jennings G, Debinski H, Lambert G, Jones P, Crotty B, Colman J, Willett I. Increased sympathetic nervous activity and the effects of its inhibition with clonidine in alcoholic cirrhosis. Ann Intern Med 1992; 116: 446-455.

71 Lopez-Novoa JM, Martinez-Maldonado M. Impaired renal response to splanchnic infusion of hypertonic saline in conscious cirrhotic rats. Am J Physiol 1982; 242: F390-F394.

72 Tanaka K, Matsuda T, Morita H, Hosomi H. Depressed sensitivity of the hepatoportal $\mathrm{NaCl}$ receptors in rats with carbon tetrachloride-induced liver cirrhosis. Am J Physiol 1995; 269(6 Part 2): R1390-R1395.

73 Matsuda T, Morita H, Hosomi H, Okada M. Response of renal nerve activity to high $\mathrm{NaCl}$ food intake in dogs with chronic bile duct ligation. Hepatology 1996; 23: 303-309.

74 Scoazec JY, Racine L, Couvelard A, Moreau A, Flejou JF, Bernuau D, Feldmann G. Parenchymal innervation of normal and cirrhotic human liver: a light and electron microscopic study using monoclonal antibodies against the neural cell-adhesion molecule. J Histochem Cytochem 1993; 41: 899-908.

75 Lee JA, Ahmed Q, Hines JE, Burt AD. Disappearance of hepatic parenchymal nerves in human liver cirrhosis. Gut 1992; 33: 87-91.

76 Nam SW, Song HJ, Back SJ, Kim TH, Cho SH, Han JY, Yoo K, Lee YS, Chung KW. Decreased hepatic nerve fiber innervation in patients with liver cirrhosis. Gut Liver 2007; 1: 165-170.

77 DiBona GF, Sawin LL. Hepatorenal baroreflex in cirrhotic rats. Am J Physiol 1995; 269(1 Part 1): G29-G33.

78 Tordoff MG, Schulkin J, Friedman MI. Hepatic contribution to satiation of salt appetite in rats. Am J Physiol 1986; 251(6 Part 2): R1095-R1102.

79 Morita H, Tanaka K, Hosomi H. Chemical inactivation of the nucleus tractus solitarius abolished hepatojejunal reflex in the rat. J Auton Nerv Syst 1994; 48: 207-212. 